\title{
CONSTRUCTION OF THE SACRED IN THE MOVING IMAGE
}

\author{
Inês GIL \\ Universidade Lusófona de Humanidades e Tecnologias, ECATI, Lisbon, Portugal \\ ines.gil@ulusofona.pt
}

\begin{abstract}
Contemporary moving image (film and video) is looking for a new form of expressing the sacred, after decades of refusing all kinds of explicit "religious" content. The notion of Sacred changed with the social evolution and today its representation is directly related to the image of reality, that allows a sincere and immediate contact with the viewer. The body's image can be a strong mediator between the expression of the sacred and reality, because it questions the position of man in the world and its relation to others. Bill Viola and The Dardenne Brothers among others, are directors who work with a totally different cinematographic form but they have the same challenge: to reveal the potential sacred of life through light and image movement.
\end{abstract}

Keywords: Film, Sacred, Realism, Body.

\section{INTRODUCTION}

A "new sacred" art with new forms of expression has established itself in our western contemporary culture. This sacred art shows new contents and refuses the traditional styles. The modernity of the sacred has been possible because of the rejection of the obvious religious image, and its exhausted use.

Today, the notion of sacred itself has evolved and is no longer a concept which meaning is exclusively transcendental; actually, it is often used to promote universal human values. For example, film and video have explored in very subtle ways the possibility of revealing this "new sacred", through the new technologies. The image of the body has been decisive: since the embodiment of the Christian deity has been the key of the divine image, it is consistent that it has also been the way to express the "new sacred" in contemporary moving image. Gilles Deleuze saw the body as an element of time expression (The Time-Image); we ask if this representation couldn't be an expression of the "new sacred". Without God (Nietzsche), the human being has to face his finitude and his loneliness in an incomprehensible world. But the absence of God can also be a sign of the sacred. Contemporary cinema and video are also interested by the concepts of transgression and inversion to implicitly introduce the sacred. The work of video artist Bill Viola and filmmakers Dardenne Brothers among others, will allow us to show how contemporary digital filmic image can reveal a new form of the sacred through the body representation. First, we will study the notion of "new sacred" in general and after we will apply it to the contemporary video and cinema. Based on these examples, we will analyse how the new sacred is expressed, particularly through the filmic image of the body.

Secularization of western societies set aside religious practices that only interest a limited number of believers. Art itself turned away from the idea of transcendence, and to do so, for a long time it transgressed religious institution through blasphemy for example. Nowadays this transgression doesn't make sense anymore, because the religious issue - and partly the catholic one - has run out of steam. There is a new reflection upon the notion of belief, directly linked to realism that questions human nature and its relation to the other and to the world, insisting on its limitations and on its finitude. How and what do we believe in? These are the issues that led again to religious themes such as the fall, redemption or death, and that allow artists to express their point of view in a new perspective, which focuses more on interrogations than criticism. 
The body is a mediator between reality and sacredness, caught between the two, or better yet: its material nature becomes sacred when it is directly involved in consciousness. To express this revelation, new technologies can be a powerful tool, especially digital video image, because they allow the video-artist to represent the relation between the body and the sacred through the profundity of light. Bill Viola used a new optical device to represent the idea of resurrection of the body in a transcendental way. In "Ocean Without a Shore" (2007), just as reality is more connected to experience than to knowledge, it is the image of the body that brings the unknown realm of death into our reality, through its transfiguration (Fig. 1). The body, which is not material in the first, finds its materiality through light in the second for it becomes visible in its almost hyper-realistic appearance.

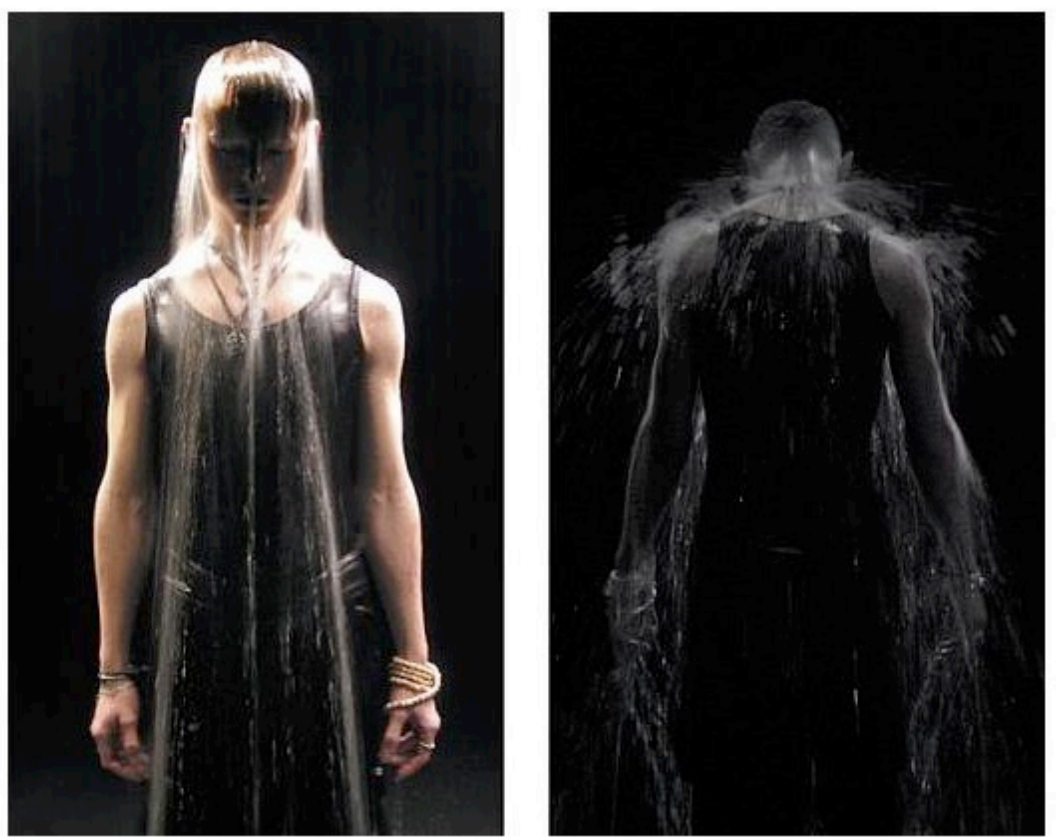

Figure 1. Bill Viola, Ocean Without a Shore, 2007.

In his images, the American video artist creates atmospheres that transform the perception of time (and space) but at the same time, and through the perception, the presence of the viewer is reinforced toward the work of art. Bill Viola shows that if knowledge, that is a western concept, illuminates us, and makes reality perceptible and intelligible, mystery allows us to go further, to an unknown place where we can discover something new. The endlessness of mystery leads us to infinite discovery and contact with something new. Video art gave a new energy to the image through the representation of movement but also of time. It's not like a painting that remains the same throughout time: when a video ends, it no longer conveys life. It's its visibility and experience that are at stake. Bill Viola asks himself why do we exist at the same time inside our body and outside from it. His work is based on this tension, between the external image of the body (and its sensations) and the internal world (rational and emotional). That is why he says that his work is about "the realism of emotions and sensations, perceptions or experiences (...) realism of the perceptions of the objects, not of the object in itself' [1].

In contemporary cinema, the representation of the fall refers to consciousness and to the ordeal of human condition. It places the human in a regressive state and leads to disorder: it provokes chaos. The fall can also help one to experience humility through consciousness of human finitude, with ultimately a desire of being saved [2]. More and more, it is reality that is summoned by the cinema for it is through life experience that directors strive to approach and question the world. No artifice, just reality in and of itself. Cinematographic social realism (that is not exactly Bazin's realism) allows a meeting between the image and the intimate 
experience of the world as life experience. The form of reality almost always goes through the representation of man. Directors even refuse to intervene in the image as if the image itself were capable to express reality in its purest state. Therefore, there is no need to stylize the world. It's a matter of "speaking" reality so that the viewer can "hear" it better. The contact between the image and the viewer is instantaneous. The sacred has moved: it's no longer in the expression of transcendence for it is in reality that the immanent truth reveals itself.

The expression of suffering is best represented by realistic cinema because the image of reality deeply touches the viewer who doesn't feel the screen between himself and the film: he's a part of the reality of the image. In a way, reality replaced the catholic institution, which imposed its dogmas. Since there is no need to keep fighting religious tradition (it doesn't have very much impact on society anymore), lack of faith, which had been an expression of freedom before, is today felt as a missing path for man to relate to the world. Because it creates a new form of communication, that is individual and collective, profound and infinite, transcendence allows an experience that goes beyond the surface of reality and urges man to reach consciousness. Nowadays, cinema shows that religion is implicit in reality, because it is in this reality that the truth is genuinely and directly expressed.

In My Joy, directed in 2010 by the Ukranian Sergei Loznitsa, the main character, the truck driver Georgy, is a victim of the inhumanity of man. After a serial of bad encounters, Georgy's mind lost its capacities and his body is reduced to a passive being. This is the discontinuity of the narrative that is looking for a coherent world, but doesn't find it. As in $\mathrm{Au}$ Hasard Balthazar, directed by Robert Bresson in 1966, alienation and evil are part of reality, and the image of reality allows the questioning of it. How is it possible to live in a reality that lost its humanity and privileged the idea of an objective to reach, without regarding to the means that have to be used? Since the body is a mediator between the spirit and the world, it is its consequences that have an impact on reality. When, at the end of My Joy, the characters truly become savages, having completely lost the sense of humaneness, it is Georgy, or rather Georgy's body, that not being able to stand it any longer, ends the violence through the extreme violence of murder. However this is also his way of saving a world that had lost its humanity. The challenge here is to find where the sacred can hide, in a world without rules and compassion... Maybe it stands into the compassion that the viewer feels for Georgy, when he finally ends with the unbearable human insanity and frees both of them.

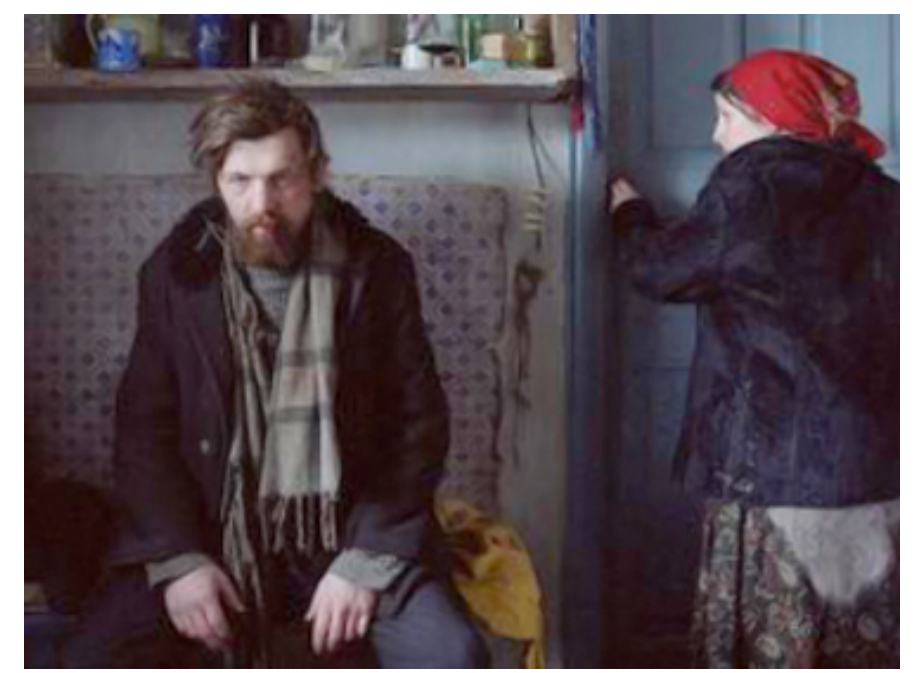

Figure 2. Georgi's body, in My Joy, Sergei Loznitsa, 2010.

The Dardenne Brothers work with the notion of "pure realism". They use the camera, not to build reality, but to unveil it. It is also in material depuration that spiritual disarray manifests itself [3]. It is therefore human fragility that is at stake, in its quest for survival and immortality. We always wonder, whether the main characters of their stories are fighting to 
live, or fighting against existence. And it is there that lies the mystery: if images must not be a destiny (such as reality could be to man), man has to take care of himself in order to discover himself and to bloom. In realistic films, bodies express their suffering and make the viewers react; this is why they cannot be sentimental. Sentimentalism, just like morbid pity anesthetizes the viewer instead of urging him to act. There is no indulgence in suffering in the image. Bodies are never mute; they scream their outrage.

The body is a reflection of the relation between man and world. For example, a sick body reveals a malaise that is also a rupture between oneself and reality; in their movie, The Son, directed in 2002, The Dardenne Brothers show us that "salvation" is necessary and that it is possible through the recognition of others and with others. Olivier, a carpenter who works as an employer at a rehab Center, happened to take his son's murderer as an apprentice, by chance. The relation that grows between the two men is ambiguous, and Olivier is definitely divided between hatred and forgiveness. The violence that exists between the two is created through a physical distance produced by an optical figure: the lack of depth of field secludes each character in his own external and internal space. Olivier's body is massive, strong and always dynamic; the camera follows his movements and his restless breathing. In this cruel situation, it looks like that there is no place and no way to be at peace. Dardenne Brothers hate the idea of a fatalist void as a human condition. They believe that man has the possibility of finding oneself, and this capacity is sacred: for example, even if forgiveness is transcendent feeling, it is a real liberating process. In any case, "salvation" is essentially terrestrial since it must happen in the "here and now" and not on a transcendental level. The way in which the bodies are filmed, without ever being overwhelmed, emphasizes the idea of the body as a mediator between reality and desire. Often, behind the characters, the camera does not try to dramatize the action using emotions. The Dardennes Brothers refuse stereotype and respect reality and its mysteries. The world's ambiguity, so important to Bazin, should be present in the image and leave the viewer interpret what he sees, in his way, with his subjectivity.

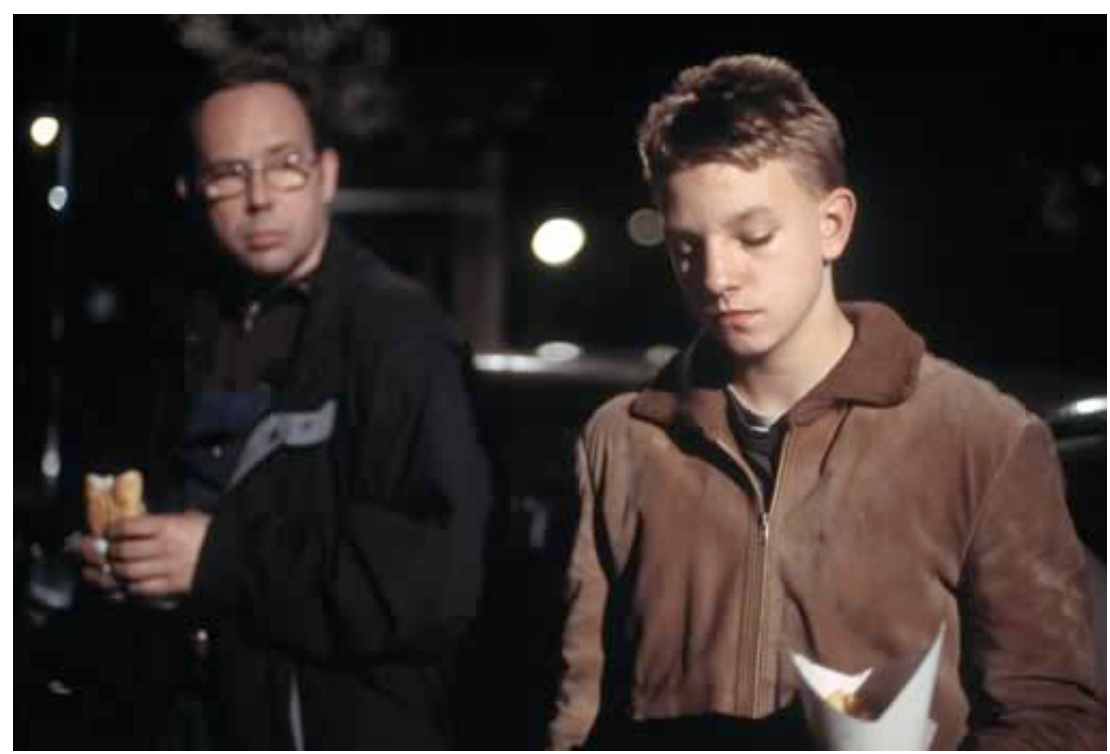

Figure 3. Olivier and Francis, in The Son, Dardennes Brothers, 2002.

With realism as revealing of the sacred, the image changed its status: it is no longer perceived as a simulacrum but on the contrary, it brings into mind of a transcendental expression in its purest form, turning into its referent. Cinematographic realism sets man in the heart of the world and provides him with a right relation. The trivial, death and the meaning of existence are themes that re-establish a link with spirituality, based on the conception that the human being lives through its body and has a profound relationship with everything that surrounds him. Gilles Deleuze showed that the body is a truly mediator between reality and time because it manifests the experience of life [4].Contemporary film and video are each time more 
interested by the expression of the sacred based on the image of reality because it is through the realistic image that humanity reveals itself, in its immediacy and sincerity. Modernity has been fundamental to transform the notion of sacred in arts; after its denial as an intangible entity, it is now reconsidered as a concept that is immanent to man's existence, as he passes through it.

\section{REFERENCES}

[1] Townsend, C.(2004). The Art of Bill Viola. London: Thames \& Hudson Publishing.

[2] Grenier, C.(2003). L'art contemporain est-il chrétien ? Nîmes: Jacqueline Chambon Publishing.

[3] Dardenne, L.(2008). Au dos de nos images 1991-2005. Paris: Seuil Publishing.

[4] Deleuze, G.(1985). L'Image-temps. Paris: Minuit Publishing. 